Cahiers d'études africaines

$230 \mid 2018$

Photographies contestataires, usages contestés

\title{
The Dynamics of Context: Reflections on the Changing Meanings of Sam Nzima's 16 June 1976 Photograph
}

Les dynamiques du contexte : réflexions sur les transformations des significations de la photographie du 16 juin 1976 prise par Sam Nzima

\section{Feizel Mamdoo}

\section{OpenEdition \\ Journals}

Electronic version

URL: http://journals.openedition.org/etudesafricaines/22117

DOI: 10.4000/etudesafricaines.22117

ISSN: $1777-5353$

Publisher

Éditions de l'EHESS

\section{Printed version}

Date of publication: 1 June 2018

Number of pages: $399-428$

ISBN: 978-2-7132-2742-4

ISSN: 0008-0055

Electronic reference

Feizel Mamdoo, "The Dynamics of Context: Reflections on the Changing Meanings of Sam Nzima's 16 June 1976 Photograph", Cahiers d'études africaines [Online], 230 | 2018, Online since 01 June 2020, connection on 06 January 2021. URL: http://journals.openedition.org/etudesafricaines/22117 ; DOI: https://doi.org/10.4000/etudesafricaines.22117 


\title{
Feizel Mamdoo
}

\section{The Dynamics of Context}

\author{
Reflections on the Changing Meanings of \\ Sam Nzima's 16 June 1976 Photograph*
}

I have a relationship to the iconic image of the 16 June 1976 uprisings in Soweto by Sam Nzima (fig. 1) that goes back to 1976 itself: as an antiapartheid activist and, post-apartheid, as a filmmaker, motivated verily by the meaning that the image held for me as an activist. This paper engages with and contributes to the discussion on Nzima's image, essentially from those loci, with an emphasis on the social and political contexts that have shaped changing readings and meanings of the image, which serve to highlight the measure of the photograph in, and of, the country.

Discussing a debate among South African artists about the role of the arts as South Africa experienced changing "political and cultural" conditions from the 1980s into the 1990s, Simbao (2007: 55) raises the question "of what happens to an emblematic image of protest as the climate of resistance shifts and as a homogenous history is conscientiously pried apart." She goes on to show how the Nzima image "seems to take on new meanings in its recontextualization" and, with reference to Joel Snyder, did not have an "unequivocal meaning to begin with." For Simbao (ibid.: 57), Nzima's image as "a cultural icon [...] was, in the hands of anti-apartheid protestors, used as if it were an image of uncontested meaning." According to Snyder (1984: 90), discussing the documentary nature of photography, "documentary is a classificatory category that is established by use and not by essential character." To dispense with a notion of documentary photographs as objectively representational of "facts," has the "analytically more important value of permitting us to see that our notions of document, record, objective picture, and the like are not fixed and determinate, but on the contrary are flexible, open, and changeable" (ibid.: 93). In Simbao's (2007: 58) words: "Sam Nzima's photograph has opened up to

* With due acknowledgement of Sam Nzima for his seminal representation and making of history and the Sam Nzima Foundation for its custodianship and promotion of his legacy. 
multivalent readings, relying, in Joel Snyder's sense, more on contemporary usage than on an ontological documentary core."

This was brought home to me strongly sometime in August 2015 when I was invited by the University of Johannesburg to present my documentary film, What Happened to Mbuyisa? (Mamdoo 1998), as part of a series of seminars organized by the Department of Sociology and the Department of Anthropology and Development Studies. The experience showed the image not to be immutable, and readings of it not bound by the conditions of its place in time. Instead the image is rendered dynamic by context.

The 1998 film tells the story of the mysterious disappearance of Mbuyisa Makhubu, the anguished young man in Nzima's photograph carrying a dying or already dead school child, Hector Pieterson, shot by police, with Hector's distraught sister Antoinette running alongside.

Mbuyisa was forced to flee South Africa as a direct result of the photograph. This consequence evinces the national and international impact of the image. In laying bare the brutality of the apartheid state, which was the immediate primary reading of the photograph, generally in Black communities and by people opposed to apartheid internationally, the photograph brought great interest to bear on Mbuyisa by the security police. Seeking to obfuscate the deaths of children by their hand, the state accused him of having posed for the photograph (Mamdoo 1998). Security police, on the hunt for him, showed children in the streets of Soweto the photograph, and when they discovered where he lived, conducted raids in search of him (ibid.). Mbuyisa, who had gone into hiding, eventually clandestinely left the country for Botswana before going on to Nigeria on a United Nations scholarship. There, in 1978, he mysteriously disappeared, never irrefutably seen or heard from again until a dramatic supposition, in 2014, that a man imprisoned in Canada since 2004 was, in fact, Mbuyisa (Sosibo 2014).

Sam Nzima, the photographer, also suffered from security police threats and harassment. He was forced to leave Johannesburg for his rural ancestral home in Limpopo province, where he opened a bottle store and forever give up professional photojournalism (Mamdoo 1998). ${ }^{1}$ This is where my documentary film found him in 1998.

1. See B. Molosankwe, “'Hector Pieterson Pic Ruined My Life,” IOL News, 06/12/2013, where S. Nzima is photographed by Bongiwe Mchunu, posing with the Pentax camera he used in Soweto in 1976, and wearing a teeshirt bearing a montage of his original photograph reproduced in the shape of continental Africa, $<$ https://www.iol.co.za/news/ south-africa/gauteng/hector-pieterson-pic-ruined-my-life-1531027>. 
Fig. 1. - SAM NZIMA'S ICONIC PHOTOGRAPH OF THE 16 June 1976 UPRISINGS IN SOWETO, SOUTH AFricA.

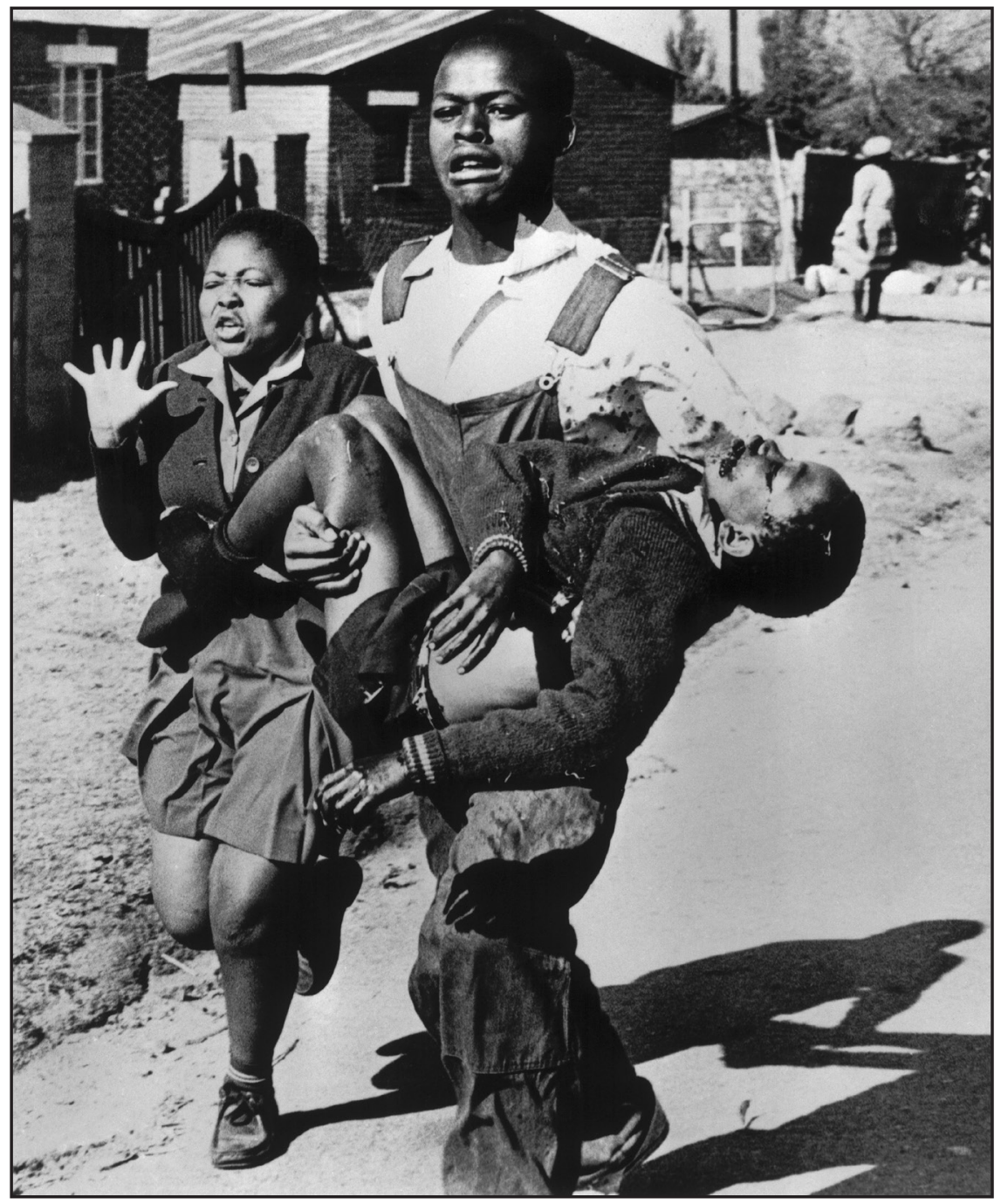

(C) Sam Nzima, 1976. Courtesy Sam Nzima Foundation. 
My introduction to the screening contextualised the film as having been made in 1998, already some twenty-two years after the events of its depiction ${ }^{2}$ which made it, at the time of the university seminar, seventeen years old. I mentioned, in passing, that the film had had many screenings on public television and at festivals and had been in demand, in its early years, as part of annual commemorative events of the June 16 massacre. With a sense of what may refer to Snyder's "deontologized notion of documentary," extended to my documentary film, I was interested in how the film would be experienced and read by an audience so many years later. I was particularly interested too in the basis for discussion it offered of the political generational divide between the young students of today and the generation of 1976, and how this mirrored the political generational divide between the 1976 generation and their parents then.

The film, taken with remarks in my introduction, provoked a derisive reaction from an academic staff member of the audience, a social activist to the left of the governing liberation movement party, the African National Congress (ANC). His reaction was to the iconic freezing of the brutalities of the apartheid state by the post-apartheid commemorative contexts that framed Sam Nzima's image, and my film too, when free and democratic South Africa had itself been guilty of repressive police violence and brutality, most notably the massacre of thirty-four striking mineworkers on 16 August 2012 at Marikana in the North West Province (SAHO 2015). This challenged aspects of post-apartheid South Africa's "foundational myths" (Hlongwane 2015; Marschall n.d.), in the service of which the Nzima image has been used and has come to symbolise. In this, not unfounded narrative, the new free and democratic South Africa has been birthed as a result of virtuous struggle and sacrifice against a repressive and unjust system. However, post-Marikana, in particular, the iconography and associated narrative of the brutality of the apartheid state, as represented by Nzima's image, are challenged in this representational place, role and meaning. Marikana evoked the massacres of the apartheid state, and shattered the myth of a post-apartheid state that had turned its back to such repressive brutality. As Nelson Mandela (1994) had captured it in his inaugural address as South Africa's first democratically elected President: "Never, never and never again shall it be that this beautiful land will again experience the oppression of one by another."

2. Filmmaking opportunities for Black South Africans with correspondingly new subject concerns and aesthetics only began to open up in the early 1990s with the demise of apartheid. For the history through the late 1980s, see ToMASELLI (1988). 


\section{Marikana}

On 16 August 2012, thirty-four mineworkers at Marikana in the North West Province who were on strike were shot dead by police. Seventy-eight workers were seriously injured. ${ }^{3}$ The workers were killed in the course of a protracted unprotected, wildcat strike for a much higher minimum wage of R12,500 per month. The strike took graphic form in thousands of workers, many armed with traditional weapons, occupying a hillock near the mine over an extended period.

The massacre has context that relates to gross inequality between the Lonmin mine workers and mine management and owners; the strikers' dissatisfaction with the established National Union of Mineworkers (NUM); violent rivalry between NUM and the new, more militant, break-away Association of Mineworkers and Construction Union (AMCU), which views NUM as the governing ANC's sweetheart union; violence between the workers and mine and state security forces that resulted in the deaths of four miners, two policemen and two mine security personnel in weeks leading up to the mass shooting; and the alleged collusion between politically-connected mine directors, specifically Cyril Ramaphosa, now President of South Africa, and relevant government ministers and the police for decisive action to crush the strike. ${ }^{4}$

The police claimed they opened fire on the miners in self-defence against an attempt to attack them with machetes, spears and clubs. A commission of inquiry found inter alia that the police had effectively herded a group of mineworkers towards a Tactical Response Team that opened fire on grounds of "reasonable risk" to their lives. It was unable to make findings on the circumstances of the deaths of other miners further away. Basically, the commission recommended a further full investigation to determine criminal liability on the part of the police (Nicolson 2015).

Independent investigations by journalists and academics however point to the massacre as a wilful wanton act by the police against workers who posed no threat to their lives. Greg Marinovich (2012), a respected international photojournalist, makes a devastating case for this based on his close investigation of the massacre site and on accounts of surviving strikers and other researchers (Alexander et al. 2013). Of the thirty-four miners killed

3. Ibid.

4. Cyril Ramaphosa was elected President of the ANC in December 2017 and became President of the Republic of South Africa with the ANC's "recall" of the incumbent, Jacob Zuma, in February 2018. He relinquished his position at Lonmin in 2013, following his re-entry into politics. For details of Ramaphosa's alleged complicity, see, for example, R. Munusamy, "Cyril Ramaphosa: The True Betrayal," Daily Maverick, 27/10/2012, <https:/www. dailymaverick.co.za/article/2012-10-25-cyril-ramaphosa-the-true-betrayal/>. 
at Marikana, Marinovich deduces the majority were killed at close range or crushed by police vehicles while hiding behind boulders, some three hundred metres out of sight of the news cameras that captured the group of mineworkers herded towards the Tactical Response Team and shot frontally in a fusillade. Many of the dead and injured were also shot in the back: "It is becoming clear to this reporter that heavily armed police hunted down and killed the miners in cold blood. A minority were killed in the filmed event where police claim they acted in self-defence. The rest was murder on a massive scale," according to Marinovich (2012: n. p.).

It is interesting how Marinovich would seem to have read the site of the massacre like a sequence of photographs in the way Newbury (2012: 209) does of Ian Berry's sequence of photographs of South Africa's Sharpeville massacre in 1960. Newbury suggests there is no single image that may be said to iconically represent the Sharpeville massacre. Instead we have a set of pictures of unfolding developments that "demands a kind of looking that actively works to map them onto the space and time of an event" (ibid.). It is striking to note too how the Marikana massacre and Marinovich's reading of it recall another in the literature, the massacre at Wounded Knee in South Dakota in the United States in 1890 (Gidley 2012). There and then too, over two hundred and fifty Lakota people were killed by a cavalry in reaction to no ostensible threat. Charles Eastman (Ohiyesa), an "Indian white doctor" dispatched to look for survivors, read the proof of massacre, as Marinovich does, in the way that he found bodies "scattered along as they had been relentlessly hunted down and slaughtered while fleeing for their lives" (Eastman 1916: 111-112). Surviving photographs confirmed this (Gidley 2012).

From these observations, the challenge of Marikana to the iconic postapartheid commemorative meaning of the June 16 image is perhaps indicative of witness by imagination that is engendered by photography and, intertextuality.

\section{Intertextuality}

The meaning of the Nzima image and its use, post-apartheid, to represent a past of state atrocity that South Africa had supposedly decisively made a break with, comes under question through a kind of intertextuality described by Werner (2004). Meanings are dependent upon the image-viewer-context triad, ideas and feelings upon the viewer's experience and background and the social and physical context where the image is encountered.

The social and political context post-Marikana thus informs the countermeaning under discussion of the Nzima image. Marikana capped, at least, but 
not only, for historical detractors to the left of the ANC, the increasing betrayal of the promise of the liberation struggle for social and economic equity.

This meaning also invests in the image the "intangible" and "imaginary" so criticised by Baudelaire (1859) as not in the nature of documentary photography (cited in the talk by Snyder 2003). This is not to argue a narrower classificatory point about photography as art versus photography as "document," which is thought of as "simply a record of the visible" (Snyder 2003), but rather to consider it more as an investment of the imaginary, in order to provide a meaning that is not, at all, visibly represented in the image.

It is generally said that the Nzima image has resonance for many because it is pietà-like, evoking the image of the Virgin Mary cradling the dead body of Jesus Christ. If this pietà image association can be said to be invested in the image, then why not any other?

For The Reverend John Pridmore (2016), a retired English priest, the pietà is precisely what allows him to see other atrocities and injustices in the Nzima image. He writes:

I realise that I have seen this picture before. My memory projects a sequence of images. I see a Turkish policeman at the edge of the sand, with the tiny body of three-year-old Aylan Kurdi in his arms. I see the figure of Jihad Masharawi, cradling his baby son, Omar, killed in Gaza by a Palestinian rocket that fell short of its target in Israel. I see a Syrian father bearing the lifeless body of his son, killed by a barrel bomb dropped on Aleppo. And I see — and I hear — the howling Lear with the dead Cordelia in his arms.

\section{Pridmore continues:}

We contemplate the picture by which Hector will always be remembered, and we find it merging with all those other images of someone cradling a dead child. And then these images become one with yet another. As we ponder these pictures, we see that each is a pietà. The images merge. As Mbuyisa Makhubu approaches me along that dusty Soweto road, he extends towards me the body of the crucified Jesus. Mary laments over Hector Pieterson, lifeless in her arms.

The experience of a writer at a photographic exhibition that featured the works of seventy South African photographers and artists, "Rise and Fall of Apartheid," at Museum Africa in Johannesburg 5 is further instructive of how Marikana is now being read in images of apartheid atrocity as well as in other images that solicit it. With reference to an image of a mass funeral for

5. The exhibition "The Rise and Fall of Apartheid: Photography and the Bureaucracy of Everyday Life," after a world tour, was held from 13 February-29 June 2014, at Museum Africa in Newtown, Johannesburg. 
protesters killed at Sharpeville and, another of Cyril Ramaphosa with mining magnate Harry Oppenheimer, the writer at the exhibition states:

Seeing the mass of bodies, I could not but think of Marikana. It was not the only time; fairly or not, I thought of the massacre and the strange entanglement of business and politics when I saw a 1985 picture of a slightly bemused trade union leader ${ }^{6}$ outstaring the country's undisputed mine boss. The older man is Harry Oppenheimer and he shares a stage with Cyril Ramaphosa. In one picture, we see how unfathomably South Africa has changed; and how much it hasn't (eNCA 06/03/2014).

Among South Africans, the use of Nzima's image to represent the myth of a post-apartheid state that avows state atrocity, provokes a "counter" reading of what is then seen in the image. This is finely distinct from the meaning of an image positively "established by use" as per Snyder and Simbao. Marikana seems now to occasion a shift in that meaning of the iconic image. Yet as a symbol of the sacrifices made for a free and democratic South Africa, that "has changed" and "hasn't," the image may also stand as conscience to the failings and betrayal of the promise of a post-apartheid South Africa. This may be for none more so than the youth of South Africa today, in particular the student youth, labelled "born free" as a generation.

\section{"Born Free"}

In an official commemorative context post-apartheid, Nzima's image has been used to pay tribute to the sacrifice of the young people of 1976 for the freedom that South Africa enjoys, particularly by the so-called "born free" youth, i.e., young people born after the first democratic elections of 1994.

There was a charge, in the first few years of democracy, that young people were insufficiently conscious of the costs with which their freedoms and opportunities had been achieved; that they were apathetic and inclined more to hedonistic pastimes. ${ }^{7}$ As if in confirmation of this, Nzima's image was adapted in anonymous spoof recreations on Facebook and other social media (fig. 2), with drunken youth posing to substitute for Hector, Mbuyisa and Antoinette.

6. Ramaphosa was a founder and leader of the National Union of Mineworkers (NUM).

7. See, for example, Baines (2007: 300-301) and HLongWane (2015: 108-111). 
Fig. 2. - Spoof of Nzima's Iconic 16 June 1976 Image on Social Media Used to Represent the Post-apartheid Preoccupations of Young People

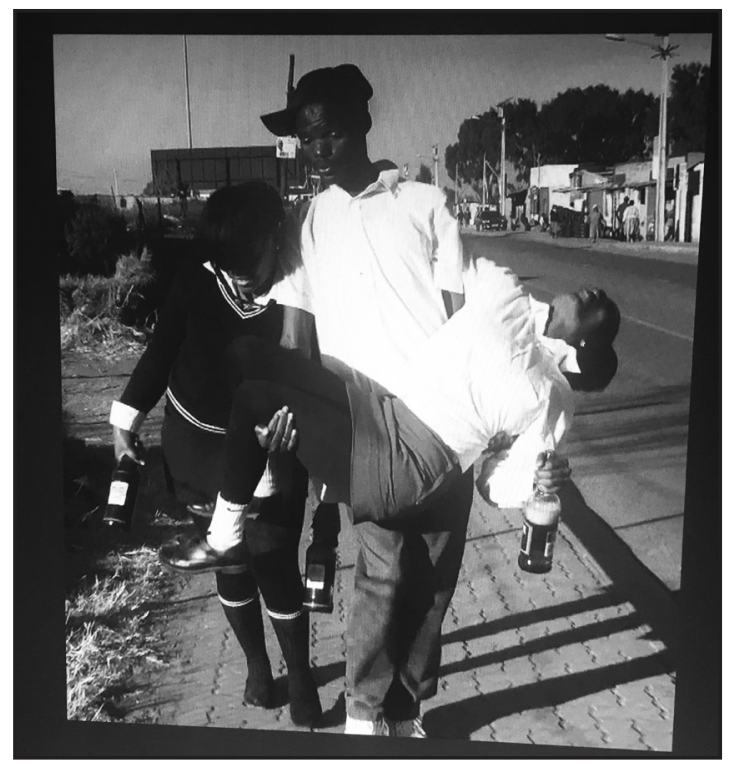

Retrieved from <https://kairossouthernafrica.wordpress.com/page/23/> posted June 19, 2012 by Kairos Southern Africa, with acknowledgment to Dr. Ben Khumalo-Seegelken.

While some of these images may be read as cocking a snook to the meaning of sacrifice represented by Nzima's image, ${ }^{8}$ others seem and may be read to convey critique of the preoccupations of post-apartheid youth compared to that of the 1976 generation. This would be akin to the way in which the producers of the satirical animated sitcom, The Simpsons, reframed meaning of Joe Rosenthal's famous Raising the Flag on Mount Suribachi image of 1945, which represents the heroism of American troops during World War II. Hariman and Lucaites (2007: 110, quoted in Saayman-Hattingh 2011: 176), read the Rosenthal image as a moulded potato chip in an episode of The Simpsons as follows:

Homer Simpson, the paragon of unfettered desire, is bequeathed a collection of potato chips molded in the form of celebrities [...]. When he comes across a potato chip in the form of the flag being planted on Mount Suribachi, he immediately acknowledges its cultural significance by uttering, "Uh-oh!" Then, after contemplating it for no more

8. See, for example, "June 16 Spoof Picture Angers Facebook Users," Sunday Tribune, 19/06/2011 <https://www.pressreader.com/south-africa/sunday-trib une/20110619/281702611336006> (accessed 25/09/2017). 
than two seconds, he succumbs to temptation, pops it in his mouth and eats it. Instead of the individual sacrificing himself to the community, we have the communal icon being sacrificed to the most banal of individual desires, the impulse to eat junk food. The image, which began as a sacred emblem of the nation's greatest collective achievement and a model of civic identity, is profaned in potato paste as a symbol of the nation's love affair with commercial consumption and an unbridled and fragmented individualism.

But since the emergence of critical university student movements in the form of \#RhodesMustFall and \#FeesMustFall in 2015, this narrative of an apathetic post-apartheid youth has been dramatically stood on its head.

The \#RhodesMustFall movement grew out of student protest action at the University of Cape Town against a statue of Cecil John Rhodes, the colonial-era mining magnate and Prime Minister of the Cape Colony. It was the cutting point of protest not only against what \#RhodesMustFall perceived as positive memorialisation of colonialism, "the perfect embodiment of black alienation and disempowerment," but continued institutional and structural racism in a Eurocentric academia and a South Africa that had supposedly liberated the African people. Decolonisation is the stated aim. ${ }^{9}$

Similarly, the \#FeesMustFall student movement, which arose in response to university fee increments, calls for the decolonisation of universities and of society and is critical of the lack of depth of transformation of South Africa post-apartheid (Hassan 2017).

The post-apartheid student movement has turned a powerful spotlight on South Africa's negotiated transition, "challenging the idea of a rainbow nation" that has yet failed to overcome stark, racially-based inequality, poverty and structural racism (ibid.). Instead, the leaders of the generations that had liberated South Africa are now critiqued to be "on the other side [...] captured by capital [...] by a different life" (ibid.). In this context, Nzima's image, as representative of a generation and a struggle to which the "born-frees" owe their questioned, democratic freedoms and opportunities, may conceivably stand for a generation that has "sold out" and/or as conscience to that generation, the representative leadership of which is seen now as part of the establishment.

This political generational tension recalls that between the young generation of 1976 with their parents. This notwithstanding, parents in the late 1970s did organise themselves in support of the students, such as in the Black Parents Association, and intervened in the educational crisis of the time. Among the complex intergenerational issues noted by Pohlandt-McCormick (2005:

9. The UCT "Rhodes Must Fall Mission Statement" (2015) is available online, in PDF format and on the Facebook page of the movement: $<$ https://fr-fr.facebook.com/RhodesMustFall/ posts/1559394444336048> (accessed 25/09/2017). 
chap. 6) were parents' feelings that they had failed their children politically; their inability to protect their children from the police; concern about prolonged boycotts of classes; displeasure at the destruction by young people of schools and other community facilities; and generally disrupted relations because of the repressive climate, with children, for example, being secretive about their activities, having to go into hiding and the like. There was, at times, violent intergenerational conflict, as in August 1976 when students enforced stay-aways from work. Hostel-based Zulu migrant workers, in particular, reacted violently to the exhortations of young township residents to support their struggle activity (Magubane 1996; Nieftagodien 2016). Multiple other factors were also at play in this, including the social and political allegiance of migrant workers to the state-collaborating Inkatha Freedom Party of Zulu chief, Mangosuthu Buthelezi. But in the words of photographer Peter Magubane, testifying to the Truth and Reconciliation Commission (1996), "anything that was young was killed."

In my own experience as a young person in Lenasia, which neighbours the Indian South African designated Group Area by about 10 kilometres, when I was politically awakened with others by the events of 1976 in Soweto, debate raged with our elders over support for the students of Soweto. We were especially critical of our parents' acquiescence. At the time, there was scant knowledge of our elders' histories of mass campaigns against apartheid in the 1940s and 1950s, and appreciation of the enduring toll, including psychological fear, of the repression that followed Sharpeville in 1960. As a new, young generation we were uncompromisingly demanding of immediate fundamental change. As Black Consciousness supporting youth, influenced by the ideas of Steve Biko, the Black Consciousness leader who was brutally murdered in detention in 1977, we rejected categorisation of an immutable Indian ethnicity and polarisation from Black African people with whom we sought to make common cause. Again, because of the climate of repression following 1960, there was little knowledge of the joint mass action campaigns by Black African and Indian South Africans in the 1940s and 1950s.

Despite the laudable progressive provocation represented by the youth of 1976, we had yet to learn sufficiently the need for maximum, communitywide participation in the Struggle, and the art and methods of consultation, mobilisation, organisation building, tactics and strategy to achieve it. Indeed as those of us who were exposed, in particular, to the ANC through the course of the late 1970s, appreciation was gained of the need to overcome a limited student-centred conception of revolution; to take a long view, including backward to a past rich in struggle on which we needed to build; to mobilise, organise and ensure the widest and maximum possible participation of people 
in struggle; to appeal to communities' felt needs and the concrete manifestations of apartheid as a basis of mobilisation and organisation rather than exhortations based on abstractions and assumptions of high levels of political consciousness and commitment.

Similarly, one may be critical of some of the attitudes of today's student movements, including an ahistorical, hindsight dismissal of South Africa's negotiated transition in 1994, its imperatives for peace, stability and social cohesion, and of its important post-apartheid achievements. It is the very conditions of a post-apartheid constitutional democracy, including freedom of expression rights, that promotes multiple and powerful counter-narratives of the freedom struggle as has been experienced. But history, not least in South Africa, suggests that young people are objectively, recurringly, a motive force of social change. In this sense, perhaps the image of Hector, Mbuyisa and Antoinette may stand, abidingly, in representation of that mission of young people for a youth now demanding greater and deeper necessary transformation.

While the student movements per se seem not to have explicitly adapted Nzima's image as "conscience to" and indictment of post-apartheid South Africa ${ }^{10}$, other adaptations, before the emergence of \#RhodesMustFall and \#FeesMustFall, have.

These relate the image to pertinent, present day struggles and concerns of young people, such as HIV, gender-based violence, unemployment and educational access (fig. 3).

Zapiro, the well-known South African cartoonist, also reproduced the image with 12-year old AIDS activist Nkosi Johnson, who died as a result of AIDS-related infection, in the arms of Mbuyisa. It was accompanied by the caption: "Champion of the New Struggle" (Saayman-Hattingh 2011: 179). The drawing evoked the struggle against apartheid and its casualties as analogous to the struggle against AIDS- but it could also be read as an indictment of the Government's AIDS-denialist policies responsible for thousands of deaths under Thabo Mbeki between 1999 and 2008, which Nkosi Johnson actively resisted.

Simbao (2007) notably provides other examples by artists that "recontextualise" Nzima's image and offer "multivalent readings" of it, such as Kevin Brand's Pietà on the wall of the Castle of Good Hope in Cape Town in 1996. But these examples are all a factor of socio-political conditions post-apartheid. As Simbao (2007: 55) says but doesn't quite show, Nzima's image never had an "unequivocal meaning" to begin with.

10. Although 16 June 1976 has been expressly invoked by the student movement. 
Fig. 3. - Evocation of NZIMA's ICONIC IMAGE TO REPRESENT POST-APARTHEID STRUGGLES

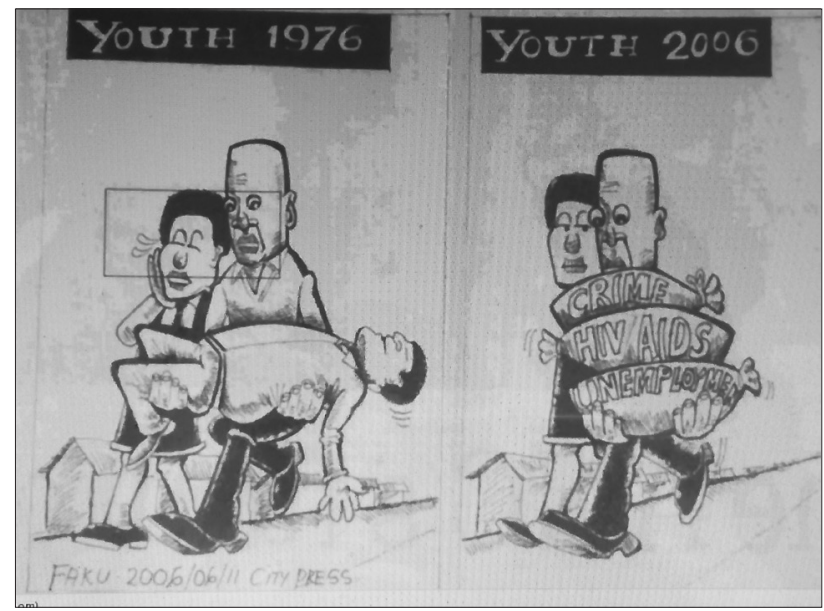

Cartoon by CFaku. Published in City Press, 11/06/2006. Source: Hlongwane (2015).

Fig. 4. - The World is the First to Publish Sam Nzima's Photograph of the Massacre of School Children on 16 June 1976

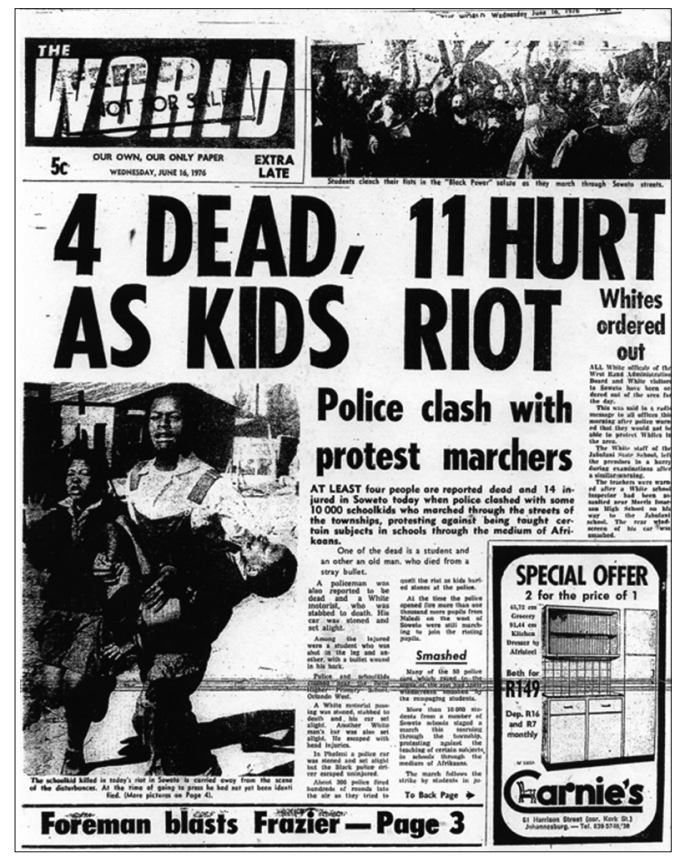

The World, "Extra Late" edition, Wednesday, June 16, 1976, front page. Retrieved from: $<$ http://time.com/4365138/soweto-anniversary-photograph/>. 


\section{The World}

Newbury (2005: 260) relates how images removed from their original contexts of production and circulation and placed on museum walls are changed. In the case of their location in museums, "the visual economy that produced these images is negated or obscured in favour of a more neutral sense of the photograph as raw material or a window onto history." Similarly, the delivery of Sam Nzima's image through the pages of The World (fig. 4), and its "removal" from this original context of production and circulation and placement in other news media, arguably made for different predominant meanings and readings.

In a highly racially-polarised society, the events of 16 June 1976 may have seemed to come "out of the blue" for the broader South African public. Yet, in Soweto, it was more of a horrific turn in developments that had been consuming Black African communities and which The World newspaper had been following for some time. Before its banning, ${ }^{11}$ The World was the most widely read newspaper by Black Africans, with a circulation of "over 100,000" (Couzens 1976: 8), and the publication was integral to the subaltern in a media landscape dominated by a mainstream press that did not reflect the lives of Black South Africans.

The World had been consistently covering the story of student, teacher and parent grievance about the imposition of Afrikaans, the spark for the uprisings, as a medium of instruction in half of all school subjects with abrupt effect from the last year of primary school (Ndlovu 2007: 327). ${ }^{12}$ The World was effectively part of the to-and-fro between community representatives and the educational authorities on the policy, opining strongly against it and covering the meetings, memoranda, sporadic class boycotts and protests related to it (Ndlovu 2007: 332-335).

As is well known, on 16 June 1976, thousands of school students in Soweto took to the streets on a march to protest the policy. At some point in the march, the students were stopped by the police, and then fired on with live ammunition. By official accounts at least twenty-three people are reported to have died that first day ${ }^{13}$ from what developed into a generalised nationwide uprising against the entire system of Banu Education and apartheid. According to the government-appointed Cillie Commission of Enquiry, 575 people died in the period up to 28 February 1977, with police action

11. The newspaper was banned in the year following the outbreak of the uprisings as part of a nationwide crackdown on oppositional Black Consciousness organisations.

12. See NdLOvU (2007) for the destructive impact of this policy.

13. "Spike: Ten things about June 16 1976," Mail \& Guardian, 14/06/2013. 
responsible for 451 of these deaths. The police were responsible for 2,389 injuries (O'Malley n.d.). Both the death and injury figures were disputed to be under-estimated.

The deaths and injuries of scores of school children as a result of legitimate, felt community grievance (and conveyed by The World) came as a shocking turn of events. ${ }^{14}$ Indeed, The World's intent in publication of the image captured by Nzima, focussed on 12-year-old Hector Pieterson, was to bring home the horror of the day's events (Baker 2016). ${ }^{15}$

Mbuyisa Makhubu's mother and sister, returning to Soweto by train from shopping in the city, got to know of the day's happenings when they bought a copy of the newspaper at the train station (Mamdoo 1998). They were confronted by the image on the front page of Mbuyisa carrying a dead school child, whom they thought to be Mbuyisa's younger brother Raul. As they made their way home, they encountered rumours by community members on the streets, strangers to them, "that even the boy that was carrying the one that they killed is also killed" (ibid.). This was information reflective of and gained only from Nzima's image, and shows how the image, as carried by The World, was quickly rooted in the swirl that engulfed the community following the shootings as it functioned, in its original site of production, to convey the ambivalent news of the massacre to its victims' closest kin.

The fact of the photograph's publication by The World, a newspaper with a long and deep history among Black African people (Couzens 1976), including through luminary community opinion makers as writers and editors (then Percy Qoboza, an outspoken critic of apartheid), and which had been consistently following developments related to the Afrikaans policy, gave it a distinct contextual meaning. It was arguably a self-reflective, internal representation, by "one's own" as it were, trusted, integrally part of the community that had suffered the horrifying tragedy and was outraged and up in arms against it. An example of how integral The World was to the life of the community and to developments, at the time, is reflected in the fact of the formation of the Soweto Committee of 10, the pre-eminently credible community representative organisation at the offices of The World in June 1977 (TRC 1998a: 591).

14. Community members and former activists, personal email communications, NovemberDecember 2017. See also PohlandT-McCormick (2005: chap. 4).

15. Though in reality not the first person to be shot and killed, Hector was martyred by the photograph and supporting news text as the very first. According to police records, Hastings Ndlovu was the first child to be shot and killed ("Youth Day: Understanding the History Behind It," Cape Talk, 16/06/2015). 
However, for non-Black African communities, the image was reproduced by other newspapers and framed by a different context that may have endowed it with very different meanings. Judging by an online auction site that offers the front page of the Late Final edition of The Star newspaper of 16 June $1976^{16}$, the popular English language liberal daily, aimed at a White readership, also published the image on the same day. Publication of the image in the mainstream press was accompanied or preceded - as in the case of the highest circulating weekly, the Sunday Times, which published the image over the weekend ${ }^{17}$ - by propagandist state television reportage. One Afrikaans newspaper reported on the June 16 uprisings with a full-page spread of images of protesting students, scenes of mayhem, and an injured person, with the condemnatory headline: "Al die dinge oor Afrikaans?" ("All these things over Afrikaans?").

Other non-media sources of information, which fed "background experiences, knowledge, and interests" as in Werner's (2004) notion of intertextuality, also shaped the environment of engagement with reports of the Soweto uprising and may have been "brought to" Nzima's image. I cannot exactly recall, but I most probably would have seen the image for the first time in The Star, which was the paper of choice bought daily by my father and read in the family. But I heard of the happenings in Soweto prior to any exposure to news reports or to Nzima's image. I remember, as a 16-year old, making my way home from a friend's in Lenasia, when I encountered a rumour in the streets, "as if planted in the wind," of a riotous Black African invasion of non-African areas. I ran home and locked the doors. As I have written elsewhere (Mamdoo 2006), it was a reaction born of fear and ignorance bred by policies of strict racial polarisation.

For White and other non-Black African South Africans who may have been exposed to the syndicated image with reports of the events in Soweto, presumably by White readership directed liberal English and conservative Afrikaans language newspapers as well as the state broadcaster, the image may have been framed by and "brought to" a predominant sense of threatening wanton violence by Black African people. This may not have been overt in liberal English-language newspapers, but was the sub-text. Steve Biko (1978: 168) too alludes to this when he refers to his reading at the time of newspapers that served White South Africans: "You get some kind of idea of the extent of fear that was prevalent in white society."

16. This front page is reproduced in facsimile online on Antiquarian Auctions: $<\mathrm{https}: / /$ antiquarianauctions.com/lots/the-star-newspaper-june-16th-1976> (accessed 17/12/2017).

17. Personal email communication with a former activist who first saw the image in the Sunday Times, 23 November 2017. 
South Africa's Truth and Reconciliation Commission (TRC), established to find post-apartheid closure and healing, confirms in its findings on the media during apartheid that the mainstream English language media "often adopted a policy of appeasement towards the state" and a "willingness [...] not to deal with matters that exposed the activities of the security forces" and that, in conclusion, the Afrikaans media "chose to provide direct support for apartheid and the activities of the security forces" (TRC 1998b: n. p.).

Not to recognise the implication for meaning of the specificity of the image as carried by The World is, at the outset, to miss something distinctive about its reception and reading by the peoples of Soweto and other Black African communities and, very possibly, contradictory readings of it in non-Black African communities at the time.

\section{Symbol of the Struggle}

From these beginnings, the image came to be invested with new meaning. An image of atrocity came, through the 1970s and 1980s, to be claimed as a symbol of resistance against oppression.

Nzima's image, syndicated to international media (Baines 2007: 286), exposed the brutal response of the South African state to legitimate protest. The picture made front page news internationally and immediately mobilised international condemnation of the apartheid regime, ${ }^{18}$ spurring the sanctions campaign against South Africa. South Africa's then Ambassador to the United Nations, Pik Botha, remembers the photograph "went right across the world, and immediately there was reaction." 19 Within days of 16 June, the United Nations Security Council passed a resolution that expressed its shock and strongly condemned the South African Government "for its resort to massive violence against and killings of the African people, including schoolchildren" (UN 1976).

The selection of Nzima's image by the American and internationally circulated mainstream publication Time, as one of "100 Photos," considered the most "influential photographs of all time," attests to its enduring global resonance. Time announced what constitutes a definition of the popular value of the "iconic" photograph as follows:

18. See, for example, BAKER (2016) and the anonymous special report from Johannesburg, "In Soweto Township, Living is a Mixture of Privilege and Passes," New York Times, 17/06/1976, p. 3, <http:/www.nytimes.com/1976/06/17/archives/in-soweto-townshipliving-is-a-mixture-of-privilege-and-passes.html> (accessed 19/09/2017).

19. This quote is from the BBC/SABC interview in 2006, cited in MARK (2016). 
Some images are on our list because they were the first of their kind, others because they shaped the way we think. And some made the cut because they directly changed the way we live. What all 100 share is that they are turning points in our human experience. ${ }^{20}$

Peffer (2012) offers more specifically how "commentators have, I think rightly, spoken of how this picture had evocative power on an international level because it may be related visually to a whole history of pietà-type images in Christian iconography."

It is not clear how strong or widespread this particular evocation of Nzima's image is for South Africans. A mentor with a post-apartheid filmmaker project in Johannesburg, who used the image to discuss issues of symbolism, says for several of his young film students it had "religious significance [...] and reminded them of the dead Jesus in the arms of his mother Mary (Pietà)."21 Interestingly, for a few of his other students who had studied fine art, Hector Pieterson's distraught sister in the image, Antoinette, recalled painter Edvard Munch's The Scream (ibid.).

However, the image's evocation of the pietà can only be a partial explanation for the resonance of the photograph. The image found and has currency well beyond members of the Roman Catholic faith, many of whom have questionable knowledge of or little to no socialised religious or cultural reference of Christian iconography. The activist community to which I belonged, for example, is largely Muslim and Hindu. The widespread resonance of the photograph has to be moreover attributed to a humanist response to an atrocity and to the political meaning it came to assume as a symbol of the struggle against apartheid.

Despite severe repression, the uprising unleashed by 16 June was not crushed and did not abate. It spread, grew, developed and intensified; wave after wave, layer upon layer of multiple, complex expressions of mass organisation, protest and insurgency into and through the 1980s right up to the democratic transition of 1994. This spirit of resistance in the face of repression came to be embodied in Nzima's image. It was used in a multitude of ways by innumerable organisations, in particular with every successive annual commemoration of June 16, engendering its iconic status, through repetition and reproduction, as a symbol of the struggle against apartheid. The image's inherent duality of atrocity and resistance is conveyed by the dead and dying Hector Pieterson in the arms of the heroic persona that is Mbuyisa.

20. $<$ http://100photos.time.com/about $>$. For the S. Nzima photograph description and video contextualisation, see $<\mathrm{http}$ //100photos.time.com/photos/sam-nzima-soweto-uprising $>$ (accessed 17/02/2018).

21. Neville Josie, personal email communication, 28/11/2017. 
Among the first to reproduce the image was the South African Council of Churches (SACC), for a Christmas postcard that lamented the atrocity that year (Nzima 2006). Student activist, now art collector, Bruce Campbell Smith, also produced a student solidarity poster with the support of the SACC for a campaign to coincide with the White Afrikaner celebration of the Day of Vow on 16 December 1976. This was a religious holiday that commemorates a battle victory against a Zulu army (Proud n.d.). Smith's posters were, however, confiscated by the police at the printing press before any distribution. Students at the then University of Durban-Westville apparently also reproduced the image in student publications as early as late June $1976 .^{22}$

Inevitably, the annual commemorative events, centred at the Regina Mundi church in Soweto, were monitored and attacked by the security forces, provoking renewed protests and more injuries and deaths (Gill 2005: 223; Hlongwane 2015: 92-93). ${ }^{23}$ The annual anniversary of June 16 became an occasion for continuous galvanising of the struggle against apartheid. Recurrently at the centre of this rallying was the image captured by Nzima. With every anniversary, and every use of the image, it accumulated additional layers of meanings of atrocity and resistance. In this context, though used as an image of "uncontested meaning" (Simbao 2007), the image was nevertheless dynamic in its relationship to processes and actors of the Struggle.

As one arts activist has noted: "This image has been used repeatedly [...] as a symbol of struggle. It has been drawn, silk screened, etched, linocut, painted, sculpted, stencilled, used as graffiti" (Seidman 2007: 121). And even within the overall meaning of the image as iconic of the struggle against apartheid, there were distinct other meanings given to the image. As one poster artist points out, each use of the photograph by the range of anti-apartheid organisations made "a new statement that belonged to their group and their time" (ibid.: 121). In the activist networks to which I belonged, for example, the image informally came to be interpreted by some in later applications, to represent a (desired) alliance between students and workers. This was because of the dungaree worn by Mbuyisa, then commonly worn by workers. This reading had as background the tensions discussed above between students and workers, and was expressive of the class content of an ideological perspective that came with exposure to and influence of the ANC. ${ }^{24}$ Mbuyisa was, in

22. Haroon Mohamed, who remembers seeing the image then for the first time in a student publication. Personal email communication, 23/11/2017.

23. Also my personal witness and experience.

24. Among the Congress movement's discourse of critique of the Black Consciousness Movement (BCM) that had influenced the 1976 generation, were its student-centredness, its focus on race to the exclusion of class, and lack of strategy to mobilise and build organisation among much broader sections of the community. 
reality, not a labourer but a recent full-time student in transition. The nation at large did not know much, if anything, about Mbuyisa through this period. And attention in the image was almost entirely focussed on Hector Pieterson.

In the dynamic contexts of the mid to late 1970s, Nzima's image cannot be said just to have been of instrumentalist use by activists. It was a vital part of the socio-political cauldron of the time, embedded in all the dynamic processes of struggle, and impactful on and transformative in return of those who used it. It was dynamic to the sharp social and political consciousness-raising of the time. It continued to be so for newer generations of activists exposed to the image in struggle literature in the 1980s. ${ }^{25}$

Yet, over time, with repeated use, the photograph was experienced also to be dulled in its human implication.

\section{Dulling of Feeling}

In the discourse and iconography of the anti-apartheid struggle, the children of 1976 came to be disembodied and abstracted as the shock troops of the revolution. An address by a leader of the South African Youth Congress to the United Nations Special Committee Against Apartheid in 1989 is illustrative in its language of this ideation: "[...] the youth, our shock troops of the revolution - the young lions" (SAHO 1989).

Simbao (2007: 54) questions what happens to the individuality of Hector, Mbuyisa and Antoinette "as their faces are endlessly printed and engraved, merging them into an iconic trio"? She references Richards (2001: 5) who says that what powerful images show "can suffer from being seen too much" and further that:

The forces that drive the production and consumption of sensational images often lead to overexposure, and through this, dulling feeling. Like the technically overexposed photograph, the scene pictured fades, an ever-weakening version of the historical moment it captures (Richards 2001: 5, cited in Simbao 2007: 54).

Hector Pieterson's sister, Antoinette, who daily experiences the photograph and its replications at the Hector Pieterson Memorial and Museum in Soweto where she works as a tour guide, reveals a change in her capacity to bear the horror of the image of her brother dead or dying. Unable to bear looking at the photograph in the beginning, she has over time been "able to put it into a kind of perspective" (Baker 2016).

25. Personal email communications with former activists, November-December 2017. 
The writer referenced earlier, at the Rise and Fall of Apartheid photographic exhibition at Museum Africa, also reveals her inurement to the image by being struck afresh, in the immediate context shaped by the exhibition and more broadly by apartheid's end, by a poignancy of lives lost futilely:

Entering the next room, you leap into the succeeding decade and are confronted immediately by Sam Nzima's photograph of Mbuyisa Makhubo (sic) carrying a dying Hector Pieterson. That image, countlessly reproduced, is too sad and potent ever to be reduced to a cliché, but we have maybe become numbed by the horror. But when I entered the room which held it and was confronted with that photograph as the futile, desperate summation of decades of dignified resistance - the shock was as if seeing it for the first time (eNCA 2014).

Again, context renders the image dynamic, but this time with a sense of tragedy born of the post-apartheid context, rather than indictment of hypocrisy or betrayal of the promise of the revolution.

My inurement to the horror of the image was similarly exposed for me in the genesis of and process of my making and exhibiting of the documentary film about Mbuyisa.

Nzima's image, in its repeated and multiple forms of publication in the context of the struggle against apartheid, was experienced on the same timescale in Black ${ }^{26}$ communities compared to that in White communities. The conditions of resistance that interacted with the image in these communities did not prevail in the communities of White South Africans. My film editor for example, a White woman, had not encountered the image before 1998. This surprised me. I had internalised an assumption that "all" South Africans of age knew the image. The image was very familiar in Black communities.

I was surprised too following a screening, many more years later, at a formerly Whites-only local school - and then still so largely. Immediately after the screening, the principal, as the very first thing, apologised and addressed words of comfort to the gathered students and teachers for the graphic images of Hector Pieterson in Nzima's photographs. My feeling of surprise at this revealed to me my own inurement, and reminded me of my very motivation in wanting to make the film after hearing of Mbuyisa's story near twenty years after the events of 1976. I was motivated to demystify and to humanise the heroic representation of Mbuyisa in the image by telling his story and who he was in flesh and blood. This was drawn precisely from the abstraction of the youth of 1976 and the people in Nzima's image. Having grown up with the image politically throughout the 1970s and 1980s, I was struck on learning of

26. Inclusive of so-called "coloured" and Indian South Africans in the Biko concept of "Black" as all racially defined groups structurally oppressed by the apartheid system. 
Mbuyisa's story from a colleague in the early 1990s, a friend of the Makhubu family. It was enough of an enormity to discover that I actually knew a live friend of Mbuyisa's family. Already the process of demystification of a person iconographically frozen was underway.

These experiences recall Campbell's (2012: 10) criticism of Sontag's "absolute and universal claims," in On Photography (1977), about images of atrocity losing their impact with repeated exposure; "because each of us will experience our epiphanies on a timescale at variance [...] What is repetitive for her will be novel for others." But relationships to images, as in the case of the Nzima image, may also be experienced on a "timescale of variance" as very large social communities and not just as individuals, and with pointed contextual framing. This shifts claims of "habituation" to the horror of certain images, in Sontag's words (as cited in Campbell 2012), to another station of complexity for consideration. As Newbury (2005: 260) writes:

Photography is central to the presentation of historical narratives about apartheid South Africa and is placed within a pedagogical framework, educating a new generation of Black South Africans about the history of the struggle, and revealing what for many white South Africans were hidden dimensions of the society in which they lived.

But the relationship to the Nzima image is not singularly related to empathy-to-atrocity. As noted above, the Nzima image is at once an image that came to be invested with meaning of resistance, not least because of the heroic figure of Mbuyisa. But for the Makhubu family, the lingering questions about the mysterious disappearance and unknown fate of Mbuyisa make the picture "a misery" (Baker 2016): "This guy just disappeared off the face of the earth," Mbuyisa's sister Nontsikelelo says. "Where is he? Did he die? If he did, how? Who was there? That's the thing that makes us miserable." In the details of the story of Mbuyisa and his disappearance, now widely known, is a further counteraction to the "freezing" of the Nzima image. There is a huge unresolved question about a central figure in the image. And in this there is a counteraction too that restores the individual, human dimensions of a person abstracted in the image.

Mbuyisa

Up until 1998, the focus in the image was primarily Hector Pieterson. But this shifted to Mbuyisa after the story of his mysterious disappearance became more widely known, not least as a result of What Happened to Mbuyisa?, broadcast a number of times on public television. In the context of fresh angles 
continuously being sought to mark every annual anniversary of 16 June since the democratic transition, this story offered something new and compellingly pertinent. A Soweto artist, for example, with reference to Mbuyisa's wish to escape Nigeria for Jamaica, popularly revealed by the documentary, adapted Nzima's image to represent Mbuyisa in dreadlocks (Simbao 2007: 59, 62).

As Pohlandt-McCormick (2005: chap. 1) eloquently notes of Mbuyisa's mother's testimony about his disappearance to the Truth and Reconciliation Commission (TRC) in 1996:

Nombulelo Makhubu took a striking moment of resistance in the history of South Africa and tore it from the past, from the grasp of commemoration, memorialization, and symbolic representation, linking it to a present where memories reside and stories about the uprising are remembered and told.

Perhaps the irresolution of Mbuyisa's fate is indicative of non-closure still evident with regard to the brutalities of apartheid and its enduring legacies, as the young students of today give such strong voice to.

While state and society are seen to yet continue commemorating June 16 with Nzima's image at centre, with nonchalance toward any determined effort to resolve the question about Mbuyisa's fate, some members of Mbuyisa's family have been derisive. They have felt that his image was being exploited with scant regard for their loss. Mbuyisa's now late younger brother, Raul (fig. 5), took to protesting this with a cropped early poster of my film asking "What Happened to Mbuyisa?" (Simbao 2007: 63). He once walked into the Hector Pieterson Museum with journalists, posed in front of the famous image and blocked Mbuyisa's face, demanding that it be erased from the photograph (Khangela 2015: 182).

The currency Mbuyisa's story has injected into the image and into commemorations of June 16 is shown too in Simbao's (2007: 63-65) account of a spontaneous break-away march to the Makhubu home after one commemorative event.

XThe focus on Mbuyisa has intensified since a dramatic development in 2014 concerning his whereabouts, thus layering further new meaning on Nzima's image. An investigator with the Canadian Border Services Agency, after watching a June 16 broadcast, came to the conclusion that a man detained on immigration violations since 2004 was in fact Mbuyisa (Kwanele 2014). According to Canada's immigration and refugee board, the man has been living in Canada since 1988. He has assumed a number of different identities and displays symptoms of a mental health disorder. He has refused to divulge his identity because he apparently believes the apartheid system still persists. 
DNA tests to confirm his identity have proved inconclusive and attempts to resolve what is an impasse have been beset by intra-government politics in South Africa (Weiner 2016). The man has since been released under a bail programme after spending more than eleven years in detention (York 2016). Now the question of Mbuyisa's fate and whether the man in limbo in Canada may be him, is possibly inescapable to include when viewing the image today.

Fig. 5. - RAUl MaKhubu (MBuyisa MaKhUbu’s BROther) PROTESTS LACK OF ATTENTION TO THE FATE OF HIS BROTHER AT THE 2006 COMMEMORATION OF JUNE $16^{\mathrm{TH}}$

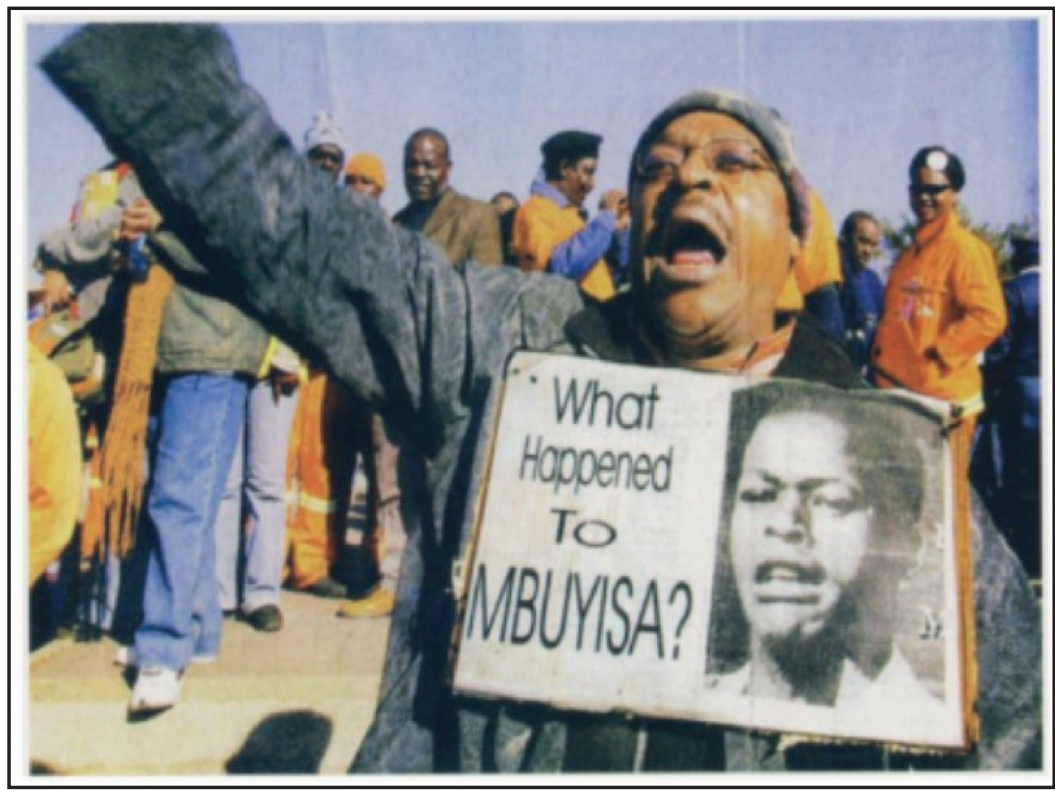

Source: SimBao (2007). Photograph by: Neo Ntsoma/Saturday Star, 2006.

Mbuyisa is constructed as a hero by this image - which is deeply embedded in the identity of South Africa - and I venture "the nation" subliminally feels a debt of gratitude to him. He personifies the courage of the youth of 1976 that made for a turning point in the struggle against apartheid. And as one Soweto resident put it, Mbuyisa signifies the care and support of the community. ${ }^{27}$ Up until the latest development, because of the mystery surrounding his fate, he has assumed a mythical aura. Now, however, if he is the man in Canada, he is flesh and bones in a tangible circumstance. Should this ever be proved with certainty and he is returned home to South Africa, it may make for a whole other meaning of Nzima's seminal photographic image.

27. Personal email communication, 4/12/2017. 
More than forty years after Sam Nzima's image of 16 June 1976 was taken, South Africa's relationship with it, in proof of its measure, is ongoing and open-ended as it continues to reference and absorb the circumstances of the country and build in multi-layered meanings.

The eternal-happenstance-moment when the photographer chances to capture the individuals who will impact the collective, the mass circulation from paper journalism to mass reproduction of derivative images, worldwide internet access, and the evolving social and political use of the image, may yet be claimed by the real lives and struggles of the subjects who have come to personify the dynamic forces of atrocity and resistance in the South African narrative. But the image has abidingly defined the lives of the protagonists personally involved with it.

Mbuyisa's mother and both of his brothers, who passionately devoted themselves to resolving the question of his whereabouts and fate, have passed on. The sole surviving member of his family, his sister Nontsikelelo, hopes for resolution in the conjecture that has surfaced in Canada. His son Thato, whom he conceived in exile in Botswana soon before he left for Nigeria where he disappeared, knows him only through the iconography of the image. Hector Pieterson's mother, Dorothy Molefe, and Antoinette, his sister, find purpose in memorialisation at events and at the museum. And Sam Nzima, in 2016, at age 82, found recognition with the Vodacom Lifetime Achievement Award for journalism. He has passed on the baton of the legacy of his photograph to his son to run with through his eponymous foundation. 


\section{BIBLIOGRAPHY}

BAINes G., 2007, “The Master Narrative of South Africa's Liberation Struggle: Remembering and Forgetting June 16, 1976," The International Journal of African Historical Studies, Boston University African Studies Center 40 (2), <https://www. jstor.org/stable/40033914?seq=4\#page_scan_tab_contents $>$ (accessed 18/09/2017).

BAKer A., 2016, "This Photo Galvanized the World Against Apartheid. Here's the Story Behind It," Time, 15/06/2016, <http://time.com/4365138/soweto-anniversary-photograph/> (accessed 19/09/2017).

Bıкo S., 1978, I Write What I Like (London: The Bowerdean Press).

CAmpbell D., 2012, “The Myth of Compassion Fatigue," < https://www.david-campbell. $\operatorname{org} / 2012 / 02 / 29 /$ the-myth-of-compassion-fatigue/> (accessed 16/11/2017).

CAPE TALK, 2015, "Youth Day: Understanding the History Behind It," 16/06/2015, <http:// www.capetalk.co.za/articles/3249/youth-day-understanding-the-history-behind-it> (accessed 20/09/2017).

Couzens T., 1976, "A Short History of The World (and Other Black South African Newspapers)," African Studies Seminar Paper, June 1976, African Studies Institute, University of the Witwatersrand, <http://wiredspace.wits.ac.za/xmlui/bitstream/ handle/10539/8608/ISS-105.pdf?sequence=1\&isAllowed=y $>$ (accessed 17/12/2017).

Eastman C. A., 1916, From Deep Woods into Civilization: Chapters in the Autobiography of an Indian (Boston: Little Brown \& Co.).

ENCA, 2014, "Photographic Exhibition Surveys our Ignoble History," 06/03/2014, <http:// www.enca.com/life/photographic-exhibitions-surveys-our-ignoble-history $>$ (accessed 24/11/2017).

Gidley M., 2012, "Visible and Invisible Scars of Wounded Knee," in G. Batchen, M. Gidley, N. Miller \& J. Prosser (eds.), Picturing Atrocity: Photography in Crisis (London: Reaktion): 25-38.

GiLl M. S., 2005, Immortal Heroes of the World (New Delhi: Sarup \& Sons).

HARIMAN R. \& LuCAites J. L., 2012, “The Iconic Image of the Mushroom Cloud and the Cold War," in G. Batchen, M. Gidley, N. Miller \& J. Prosser (eds.), Picturing Atrocity: Photography in Crisis (London: Reaktion): 135-146.

Hassan F., 2017, "We Are Woke," in COLl. (ed.), South African Civil Society and the AIDS Response: Recognising the Past, Securing the Future (Pretoria: South African National AIDS Council Civil Society Forum): 100-102. 
Hlongwane A. K., 2015, The Historical Development of the Commemoration of the June 16, 1976 Soweto Students' Uprisings: A Study of Re-representation, Commemoration and Collective Memory, Ph.D. Thesis (Johannesburg: Wits School of the Arts, University of the Witwatersrand).

Kwanele S., 2014, "Finding Mbuyisa Makhubu, the June 161976 Hero," Mail \& Guardian, 13/06/2014, <https://mg.co.za/article/2014-06-12-red-herrings-plaguesearch-for-mbuyisa-makhubu $>$ (accessed 21/09/2017).

Magubane P., 1996, "Testimony to Truth and Reconciliation Commission," Truth and Reconciliation Commission: Human Rights Violations, 22/07/1996, <http://www. justice.gov.za/trc/hrvtrans\%5Csoweto/magubane.htm> (accessed 19/11/2017).

Mamdoo F., 2006, “Feizel Mamdoo’s Aha! Moment,” O, The Oprah Magazine: 30.

Mandela N., 1994, Statement of the President of the African National Congress, Nelson Mandela, at his Inauguration as President of the Democratic Republic of South Africa, Union Buildings, Pretoria, 10 May 1994, <http://oldgov.gcis.gov.za/ speeches/1994/990319514p1006.htm> (accessed 16/12/2017).

MARINOVICH G., 2012, "The Murder Fields of Marikana. The Cold Murder Fields of Marikana," 08/09/2012, <https://www.dailymaverick.co.za/article/2012-08-30-themurder-fields-of-marikana-the-cold-murder-fields-of-marikana\#.WcUqssgjHIV> (accessed 22/09/2017).

MARK S., 2016,“South African Social Documentary Photography,” Stephen Mark, (Blog) 30/10/2016, <https://stephenmarkwilksblog.wordpress.com/2016/10/30/south-african-social-documentary photography/> (accessed 24/11/2017).

Marschall S., nd, “'Lest we forget': The 'Struggle for Liberation' as Foundation Myth," Alizés, Université de la Réunion, <http://oracle-reunion.pagesperso-orange.fr/documents/383.html $>$ (accessed 06/12/2017).

NDlovu S. M., 2007, The Soweto Uprising in The Road to Democracy in South Africa, Volume 2: 1970-1980 (Pretoria: South African Democracy Education Trust: Unisa Press), <http://sadet.co.za/docs/RTD/vol2/Volume\%202\%20-\%20chapter\%207.pdf> (accessed 16/09/2017).

Newbury D., 2005, [extract only] “'Lest we forget': Photography and the Presentation of History at the Apartheid Museum, Gold Reef City, and the Hector Pieterson Museum, Soweto," Visual Communication 4 (3): 259-295, <http://vcj.sagepub.com/ content/4/3/259> (accessed 24/11/2017).

— 2012, "Picturing an 'Ordinary Atrocity': the Sharpeville Massacre," in G. BATCHEN, M. Gidley, N. Miller \& J. Prosser (eds.), Picturing Atrocity: Photography in Crisis (London: Reaktion): 209-223. 
Nicolson G., 2015, "Marikana Report: Key Findings and Recommendations," Daily Maverick, 26/06/2015, <https://www.dailymaverick.co.za/article/2015-06-26marikana-report-key-findings-and-recommendations/\#.WcUutcgjHIU $>$ (accessed 22/09/2017).

Nieftagodien N., 2016, "Soweto Forty Years On: The Black Student Rebellion of 1976," South African History Online, <http://www.sahistory.org.za/archive/sowetoforty-years-black-student-rebellion-1976-professor-noor-nieftagodien $>$ (accessed 19/09/2017).

NzIMA S., 2006, "It Started on the $15^{\text {th }}$ of June 1976 in the Afternoon," Rhodes Journalism Review, 26/09/2006, <http://journals.co.za/docserver/fulltext/rujr/2006/26/ rujr_n26_a5.pdf?expires $=1512903334 \& \mathrm{id}=\mathrm{id} \&$ accname $=$ guest $\&$ checksum $=-$ B47A329C9F8668915889A1F9F9B9082E > (accessed 15/11/2017).

O’Malley P., nd, “The O’Malley Archive, hosted by the Nelson Mandela Centre of Memory," <https://www.nelsonmandela.org/omalley/index.php/site/q/031v01538/ 04lv01539/05lv01562/06lv01569.htm> (accessed 19/09/2017).

Peffer J., 2012, "Remarks on South African Photography and the Extraphotographic," Africultures, "Les mondes en relation," $<$ http://africultures.com/remarks-on-southafrican-photography-and-the-extraphotographic-11101/> (accessed 23/11/2017).

Pohlandt-McCormick H., 2005, I Saw a Nightmare... Doing Violence to Memory: The Soweto Uprising, 16 June 1976 (New York: Columbia University Press), <http:// www.gutenberg-e.org/pohlandt-mccormick/> (accessed 15/09/2017).

Pridmore J., 2016, “A Pietà for All Seasons,” Church Times, 10/06/2016, <https://www. churchtimes.co.uk/articles/2016/10-june/faith/faith-features/a-piet\%C3\%A0-for-allseasons $>$ (accessed 24/11/2017).

Proud H., n.d., "The Collection as the Image of the Collector," Revisions: Expanding the Narrative of South African Art, <http://www.revisions.co.za/articles/the-collectionas-the-image-of-the-collector/\#.WiE2tEqWbIW> (accessed 24/11/2017).

SaAyman-Hattingh H., 2011, "Understanding Cultural Identity and Visual Communication in the Appropriation of Iconic Photojournalism," in 20/20 Design Vision, Conference Proceedings of the Sixth International Design Education Forum of Southern Africa (DEFSA) Conference, Faculty of Art, Design and Architecture, University of Johannesburg, <http://www.defsa.org.za/sites/default/files/downloads/ 2011 conference/DEFSA\%20Conference\%20Proceedings\%202011.pdf $>$ (accessed 13/09/2017).

SeIdman J., 2007, Red on Black: The Story of the South African Poster Movement (Johannesburg: STE Publishers).

SimBao R. K., 2007, "The Thirtieth Anniversary of the Soweto Uprisings: Reading the Shadow in Sam Nzima's Iconic Photograph of Hector Pieterson," African Arts 40 (2): 52-69, <http://www.jstor.org/stable/20447828> (accessed 12/09/2017). 
Sontag S., 2003, Regarding the Pain of Others (New York: Farrar, Straus \& Giroux).

SosiBo K., 2014, "Finding Mbuyisa Makhubu, the June 16, 1976 Hero," Mail \& Guardian, 13/06/2014, <https://mg.co.za/article/2014-06-12-red-herrings-plague-search-formbuyisa-makhubu> (accessed 21/09/2017).

South African History ONLINE (SAHO) , 1989, "Statement at the Meeting of the Special Committee Against Apartheid in Observance of the International Day of Solidarity with the Struggling People of South Africa (Soweto Day), 16 June 1989," < http://www. sahistory.org.za/archive/statement-meeting-special-committee-against-apartheidobservance-international-day-0 $>$ (accessed 27/12/2017).

- 2015, "Popular Resistance and Police Brutality in Democratic South Africa," 13/03/2015, <http://www.sahistory.org.za/article/popular-resistance-and-policebrutality-democratic-south-africa $>$ (accessed 20/09/2017).

SNYDER J., 1984, “Documentary without Ontology," Studies in Visual Communication 10 (1): 78-95.

Tomaselli K., 1988, The Cinema of Apartheid: Race and Class in South African Film (New York-Chicago: Smyrna-Lake View Press).

Truth and Reconciliation Commission (TRC), 1996, "Human Rights Violations, Submissions, Questions and Answers", 30/04/1996, Testimony of Nombulelo Elizabeth Makhubu, Case GO/0133, Johannesburg, Day 3 (transcript), <http://www. justice.gov.za/trc/hrvtrans\%5Cmethodis/makhubu.htm>.

- 1998a, "TRC Final Report: Volume 3, Chapter 6, Subsection 32, SABC Truth Commission Special Report", <http://sabctrc.saha.org.za/reports/volume3/chapter6/ subsection32.htm $>$ (accessed 24/12/2017).

— 1998b, "TRC Final Report: Summary and Guide to Contents," < http://www.justice. gov.za/trc/report/execsum.htm> (accessed 20/09/2017).

United Nations (UN), 1976, United Nations Security Council Resolution 392 (1976), 19/06/1976, <http://unscr.com/en/resolutions/392> (accessed 24/09/2017).

WERNER W., 2004, “'What Does This Picture Say?’ Reading the Intertextuality of Visual Images," International Journal of Social Education 19 (1): 64-77.

York G., 2016, "Freed from Canadian Detention, South African Man Left in Limbo," The Globe and Mail, 14/06/2016, <https://beta.theglobeandmail.com/ news/world/freed-from-canadian-detention-south-african-man-left-in-limbo/ article30462108/?ref=http://www.theglobeandmail.com\& $>$ (accessed 25/09/2017).

\section{FILMOGRAPHY/VIDEO}

Mamdoo F., 1998, What Happened to Mbuyisa?, documentary film, 65 min. (Lonehill, Johannesburg: Endemol Productions). 
Roberts J., 2003, "Trauma and the Ostensive Power of the Photographic Document," paper presented at the "Photography and the Limits of the Document Symposium," 7 June 2003, video recording, 0:59:40 min. (London: Tate Modern), <http://www. tate.org.uk/context-comment/video/photography-and-limits-document $>$ (accessed $15 / 11 / 2017)$.

SNyder J., 2003, "Remarks on Cruel and Tender," paper presented at "Photography and the Limits of the Document Symposium," 7 June 2003, video recording (London: Tate Modern), 0:39:20-0:42:12 min., <http://www.tate.org.uk/context-comment/ video/photography-and-limits-document $>$ (accessed 15/11/2017).

WeInER M., 2016, Through the Cracks: The Untold Story of Mbuyisa Makhubu, podcast series (South Africa: Eye Witness News [EWN]), <http://ewn.co.za/features/mbuyisa/ throughthecracks/>.

\section{ABSTRACT}

This article contributes to the discussion on Sam Nzima's iconic image of the 16 June 1976 uprisings in Soweto. My situation, first as an anti-apartheid activist, then as a filmmaker, post-apartheid, has influenced my relationship to this image and the meaning it has held for me. This article draws on my experience in order to emphasize the social and political contexts that have shaped the changing readings and meanings of the Nzima image. Finally, this paper serves to highlight the measure of the photograph in, and of, South Africa.

Keywords: South Africa, Marikana, Soweto, Mbuyisa Makhubu, Sam Nzima, apartheid, photograph, The World, youth.

\section{RÉSUMÉ}

Les dynamiques du contexte: réflexions sur les transformations des significations de la photographie du 16 juin 1976 prise par Sam Nzima. - Cet article contribue à la discussion autour de l'image iconique prise par Sam Nzima des émeutes à Soweto la journée du 16 juin 1976. Ma situation, d'abord en tant que militant anti-apartheid et ensuite, à l'ère postapartheid, en tant que cinéaste engagé, a influencé ma relation à cette image et ses significations pour moi. Cet article puise dans mon expérience afin de souligner les contextes sociaux et politiques qui ont modulé les lectures et significations de la photographie prise par Nzima. Enfin, cet article contribue à mesurer l'importance de la photographie en et de I'Afrique du Sud.

Mots-clés: Afrique du Sud, Marikana, Soweto, Mbuyisa Makhubu, Sam Nzima, apartheid, photographie, jeunesse, The World. 